\title{
RANCANG BANGUN LOCATION BASED SERVICE SEBAGAI SARANA PROMOSI MENGGUNAKAN TEKNIK LAYANAN MOBILE COUPON
}

\author{
Ika Arfiani' ${ }^{1}$, Agus Harjoko ${ }^{2)}$ \\ ${ }^{1)}$ Ilmu Komputer dan Elektronika, Universitas Gadjah Mada \\ ${ }^{2)}$ Ilmu Komputer dan Elektronika, Universitas Gadjah Mada \\ e-mail : ikaarfiani87@gmail.com ${ }^{1)}$, aharjoko@gmail.com ${ }^{2}$
}

\begin{abstract}
ABSTRAK
Pertumbuhan pengguna layanan mobile data dan mobile internet di Indonesia meningkat pesat dibandingkan voice dan sms. Maraknya penggunaan teknologi mobile semakin membuka peluang besar bagi aplikasi web maupun mobile. Terlebih lagi adanya fase baru dalam berbelanja yakni penggunaan mobile coupon yang memungkinkan konsumen mendapatkan special offers yang bersifat pribadi dari produk kesayangan mereka, hanya dengan memindai Quick Response (QR) code menggunakan smartphone. Pada penelitian ini dilakukan rancang bangun aplikasi Location Based Service untuk memodelkan cara berpromosi dengan menerapkan teknik layanan mobile coupon menggunakan metode Push Notification untuk memberikan informasi iklan secara otomatis ketika pengguna masuk kedalam radius tertentu, sekaligus mendapatkan solusi yang optimal atas pencarian rute terpendek dari sisi jarak tempuh dengan algoritma bee colony optimization. Dimana teknik pencarian lokal menggunakan konsep forward dan backward serta nilai probabilitas suatu jalur dijadikan dasar pada proses transisi jalur, kemudian rute pilihan akan diperoleh dari durasi waggle dance para lebah yang berhasil menemukan posisi tujuan. Beberapa alternatif rute pilihan tersebut kemudian dibandingkan untuk mendapatkan alternatif rute perjalanan yang terpendek. Karena titik-titik lokasi pada aplikasi ini berupa koordinat yang pada permukaan bumi, sehingga dalam perhitungan jaraknya menggunakan metode haversine. Dari hasil pengujian sistem menunjukkan bahwa aplikasi dapat memberikan informasi promosi kepada pengguna, melakukan panggilan telepon ke merchant yang dituju, melakukan share promosi, melakukan subscribe promo, melakukan chek in tempat, serta menampilkan map sekaligus rute terpendek menuju lokasi merchant yang ingin dituju. Pencarian rute terpendek sangat dipengaruhi oleh jumlah lebah yang dilepas, yang mana semakin banyak jumlah lebah yang dilepas maka semakin besar peluang ditemukannya rute terpendek.
\end{abstract}

Kata Kunci: algoritma bee colony optimization, location based service, push notification rute terpendek

\begin{abstract}
The growth of mobile data services and mobile internet in Indonesia increased considerably compared to voice and SMS. The widespread use of mobile technology is increasingly open up great opportunities for web and mobile applications. Moreover, the existence of a new phase in the use of mobile shopping coupon that lets consumers get personalized special offers from their favorite products, simply by scanning the Quick Response (QR) code using a smartphone. In this research, design and build applications Location Based Service to model how to promote by applying the technique of mobile services coupon using Push Notification to provide advertising information automatically when a user enters into a certain radius, while achieving an optimal solution to the search shortest route in terms of mileage the bee colony optimization algorithm. Where local search techniques using the concept of forward and backward as well as the value of the probability of a track basis on the transition path that then routes the option will be obtained from the duration of the waggle dance of the bees were able to find the position of the destination. From some of the alternative route options were then compared to obtain alternative travel route is the shortest. Because the location points on this application in the form of coordinates on the earth's surface, so that the distance calculation using the method haversine. The results show that the application system can provide a promotion information to users, showing the phone calls to designated merchants, showing to share promotions, subscribe promo, showing to check in, and shows the map and the shortest route to the intended location. Where in the search for the shortest route is strongly influenced by the amount of bees were released, of which the more the number of bees were released, the greater the chances of finding the shortest route.
\end{abstract}

Keywords: bee colony optimization, location based service, push notification, shortest path

\section{PENDAHULUAN}

$\mathrm{P}$ ertumbuhan pengguna layanan mobile data dan mobile internet di Indonesia meningkat pesat dibandingkan voice dan sms. Hal ini dipengaruhi oleh semakin murahnya perangkat ponsel yang didukung dengan pertumbuhan layanan infrastruktur mobile seperti EDGE, 3G, 3.5G, 4G maupun infrastruktur telekomunikasi yang lain seperti Wi-fi, Wimax, dan LTE (Long Term Evolution) [1]. Implikasinya, bila sebelumnya banyak aplikasi standalone yang cukup dijalankan pada komputer desktop, dengan maraknya penggunaan teknologi mobile, maka semakin terbuka peluang besar bagi aplikasi web maupun mobile. Terlebih lagi adanya fase baru dalam berbelanja yakni penggunaan mobile coupon yang memungkinkan konsumen mendapatkan special offers yang bersifat pribadi dari produk kesayangan mereka, hanya dengan memindai Quick Response (QR) code menggunakan smartphone. 
Mobile coupon merupakan lead baru program promo produk melalui sistem mobile dengan mengintegrasikan $Q R$ code atau Barcode, dimana iklan akan ditampilkan dalam bentuk SMS atau MMS yang berisi promosi produk atau jasa. Iklan dapat diisi dengan teks, gambar bahkan video. Sehingga sangat efektif dan sangat terukur bagi penggunaan campaign jarak dekat. Dengan memanfaatkan mobile coupon maka iklan konvensional akan semakin jauh ketinggalan, karena mobile coupon mampu memudahkan serta mempercepat proses transaksi pembayaran di kasir karena hanya dengan memindai $Q R$ Code.

Menurut Kumar, dkk. [2] Location Based Service (LBS) adalah layanan yang menyediakan informasi berdasarkan tempat, mengacu pada GIS atau electronic map yang ditunjukkan oleh garis lintang dan bujur sehingga mendapatkan titik lokasi yang akurat. Adapun untuk mengantisipasi masalah pencarian navigasi atau rute terpendek untuk mencapai lokasi tujuan, pada penelitian ini digunakan algoritma bee colony optimization dengan faktor jarak tempuh sebagai bahan pertimbangannya dengan mengabaikan masalah-masalah yang dapat mempengaruhi waktu tempuh seperti kemacetan, lebar jalan, pengalihan arus, dan traffic light. Dimana pencarian rute terpendek ini diawali dengan mengetahui posisi asal dan lokasi tujuan (merchant) yang akan dikunjungi. Posisi-posisi ini akan digunakan untuk proses pembangunan tur perjalanan dan pencarian rute terpendek dengan algoritma bee colony optimization.

Pembangunan aplikasi LBS dengan pemanfaatan cell ID pernah dilakukan oleh Wibowo dkk [3] memanfaatkan cell ID untuk menampilkan layanan yang bereaksi terhadap perubahan entitas posisi dan informasi mengenai industri tingkat Kabupaten Bantul berupa galeri foto, deskripsi industri, kontak komunikasi pihak industri serta rute dan jarak terdekat lokasi industri. Selain penggunaan model cell ID, digunakan juga model GPS (Global Positioning System). Seperti penelitian yang dilakukan oleh Imaniar dkk [4], mampu menampilkan informasi publikasi acara beserta arah menuju lokasi acara dengan menggunakan Google Maps. Hasilnya berupa data publikasi acara yang dipetakan sesuai dengan lokasi kota pengguna berada. Namun aplikasi ini hanya diterapkan pada emulator dan server pada PC. Kushwaha [5] memanfaatkan GPS untuk mencari layanan terdekat dengan disertai security system, informasi kepadatan lalulintas, model kendaraan yang tepat dipakai untuk sampai ke lokasi yang dituju. Penerapan metode push dan pull notification pernah dilakukan oleh Machrus dkk. [6] juga membuat aplikasi Clinic Finder menggunakan metode LBS client-server, aplikasi pencarian yang dirancang ini dapat memberikan informasi alamat, letak klinik terdekat dengan posisi pengguna, serta menampilkan rute dari posisi pengguna ke klinik yang dituju. Pratama, dkk [7] menggunakan parameter indikator bensin pada sepeda motor untuk mencari layanan Stasiun Pengisian Bahan Bakar Umum (SPBU) terdekat, aplikasi ini memanfaatkan teknologi LBS yang dapat mengetahui lokasi pengguna. Aplikasi dapat menampilkan secara otomotis pemberitahuan tentang informasi posisi dari pengguna dan lokasi SPBU terdekat dari pengguna. Aplikasi ini juga menyediakan pilihan untuk menampilkan peta yang diambil dari layanan Google Maps sehingga dapat menunjukkan rute untuk menuju SPBU terdekat dari posisi pengguna. Layanan yang digunakan adalah pull dan push service.

Adapun penelitian lain mengenai Mobile Advertising pernah dilakukan oleh Hanafi [8] yang mengimplementasikan Mobile Advertising yang sesuai dengan prinsip periklanan dengan dukungan prinsip Human Computer Interaction (HCI), serta dapat mendeteksi perilaku pengguna sehingga iklan akan lebih tepat sasaran dan tujuan iklan akan tercapai. Ikhsandio [9] juga pernah membangun pengembangan server aplikasi LBS dengan menggunakan web service. Aplikasi ini hanya berupa server dan berjalan di platform Android dengan model iklan yang ditampilkan berbentuk teks dan gambar. Server dibangun dengan framework Laravel dan terintegrasi dengan Google Maps. Penelitian ini juga dilakukan oleh Prasetyo [10] dengan menggunakan metode Selected Push untuk mempermudah pengguna mendapatkan informasi periklanan secara dinamis dan dapat melakukan pencarian lokasi layanan umum di Yogyakarta.

Dari beberapa penelitian sebelumnya yang pernah ada, penelitian ini sangat dekat dengan penelitian yang pernah dilakukan oleh Prasetyo [10] yakni membuat aplikasi LBS dengan metode selected push untuk mendapat informasi periklanan dan mencari layanan umum di Yogyakarta. Serta dengan penelitian yang dilakukan oleh Rahmady [11] yakni aplikasi LBS dengan metode push dan pull pada operasi android. Namun terdapat beberapa perbedaan pada penelitian yang akan dibangun dengan penelitian yang pernah ada sebelumnya yakni :

1) Dalam membangun aplikasi LBS tidak menggunakan cell ID namun menggunakan GPS.

2) Aplikasi ini dibangun untuk membantu para pengusaha dalam penghematan biaya promosi.

3) Fitur yang akan dibangun menggunakan komunikasi satu arah dengan metode push notification.

4) Kupon promo (mobile coupon) yang dibuat telah diintegrasikan dengan $Q R$ Code.

5) Penentuan jarak lokasi merchant dengan pengguna menggunakan metode Haversine. Serta penentuan rute terpendek dengan metode Bee Colony System.

6) Pemilihan paket iklan pada tiap merchant berdasarkan pada jumlah iklan yang dapat dikirim setiap bulannya. 


\section{METODE}

\section{A. Menghitung Jarak Terdekat Dengan Metode Haversine}

Untuk proses perhitungan jarak antara koordinat lokasi pengguna dengan koordinat lokasi merchant pada aplikasi ini diterapkan metode Haversine karena Haversine Formula biasa digunakan untuk menghitung jarak Orthodromic. Jarak Orthodromic adalah jarak terpendek antara dua titik di permukaan bumi menggunakan garis lintang (longitude) dan garis bujur (lattitude) sebagai variabel inputan. Jarak Orthodromic bukan merupakan jarak garis lurus yang menghubungkan dua titik seperti pada jarak Euclidean. Jarak Orthodromic ikut memperhitungkan jari - jari kelengkungan bumi. Menurut Smart [12] Haversine Formula untuk menghitung jarak Orthodromic dapat dinyatakan dengan persamaan 1, dengan $\mathrm{r}$ adalah Radius Bumi bernilai $6371 \mathrm{~km}, \varphi$ adalah Lattitude (bujur), $\gamma$ adalah Longitude (lintang), d adalah jarak, dimana 1 derajat $=0.0174532925$ radian.

$$
d=2 r \cdot \arcsin \left(\sqrt{\sin ^{2}\left(\frac{\Phi_{2}-\Phi_{1}}{2}\right)+\cos \left(\Phi_{1}\right) \cdot \cos \left(\Phi_{2}\right) \cdot \sin ^{2}\left(\frac{Y_{2}-\gamma_{1}}{2}\right)}\right)
$$

\section{B. Mencari Rute Terpendek Dengan Metode Bee Colony Optimization}

Lebah merupakan serangga sosial yang sangat terorganisir. Koloni lebah buatan bersama-sama mencari solusi optimal dari masalah yang diberikan. Setiap lebah buatan menghasilkan satu solusi untuk masalah ini. Ada dua fase dalam satu langkah algoritma BCO yaitu fase maju (forward pass) dan fase mundur (backward pass). Lebah menggunakan aturan transisi dalam membuat keputusan untuk memilih kota yang dikunjungi berikutnya. Sekembalinya lebah ke sarang setelah membangun tur lengkap, waggle dance akan dilakukan untuk diperlihatkan bagi lebah lainya yang ada disarang. Kebijakan yang diterapkan dalam memungkinkan waggle dance adalah lebah yang berhasil menemukan sumber makanan yang diperbolehkan untuk menari. Tarian seekor lebah selain memberikan informasi jalan yang lebih pendek juga mengandung informasi durasi waktu. Dimana $D_{i}$ merupakan durasi waggle dance lebah ke-i, $\mathrm{K}$ adalah skala faktor waggle dance, $\mathrm{P}_{\mathrm{fi}}$ adalah profitabilitas lebah ke$\mathrm{i}$, dan $\mathrm{P}_{\text {fcolony }}$ adalah profitabilitas koloni lebah.

$$
D_{i}=K \cdot \frac{P_{f_{i}}}{P_{f_{\text {colony }}}}
$$

Disini sistem yang dibangun membutuhkan lokasi koordinat dari satelit GPS. Pada gambar 1. ditunjukkan arsitektur sistem dari aplikasi dimana ketika pengguna berada disuatu lokasi maka sistem akan mendeteksi apakah pengguna masuk dalam radius lokasi merchant atau tidak dengan cara meminta koordinat lokasi saat ini ke server google yang kemudian server google melalui satelite GPS akan mengirimkan koordinat lokasi user saat ini. Pengguna akan diberikan informasi promosi yang paling dekat. Dimana setelah pengguna mendapatkan iklan promosi produk dari merchant, maka sistem akan request koordinat lokasi merchant ke server sistem. Jika pengguna akan mendatangi lokasi merchant maka server akan mengirimkan peta skaligus rute tujuan yang diinginkan.

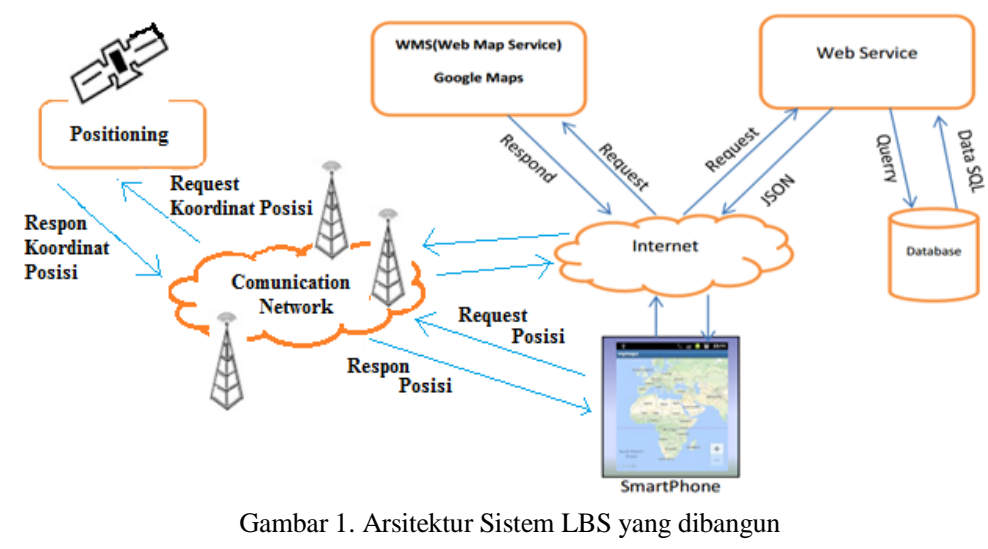

Adapun rancangan dari aktifitas jalannya sistem LBS yang dibangun pertama-tama admin aplikasi akan membuka dan login ke website pengelolaan dan menjalankan web service, ketika awal sekali belum ada data maka admin akan menginputkan semua data yang dibutuhkan seperti yang ada dalam tabel di database, kecuali data promosi. Hal ini karena data promosi akan diinputkan oleh merchant yang bersangkutan. Kemudian ketika sudah ada data merchant yang terdaftar dan melakukan permintaan untuk approved promosi, maka admin akan mengecek kelayakan promo tersebut dan melakukan approved promo untuk dapat diterbitkan sebagai notif promo. Ketika pengguna smartphone mulai menjalankan aplikasi ini, maka aplikasi akan meminta lokasi koordinat user saat ini kepada sistem GPS. Kemudian GPS akan mendeteksi lokasi keberadaan user dan menampilkan koordinat user berada. Kemudian aplikasi akan mengirim data koordinat lokasi user ke server untuk dilakukan perhitungan jarak 
menggunakan metode Haversine guna meminta promo terdekat yang ada disekitar area user. Disini server data akan mengecek keaktifan iklan yang ada kemudian mengirimkannya kepada pengguna berdasarkan subscribe yang telah dipilih, atau umum. Dengan berlangganan maka pengguna akan lebih mudah dalam mendapatkan berbagai iklan penawaran menarik dari produk yang disukai.

Setelah mendapat data promo dari merchant yang terdekat maka aplikasi akan menampilkannya ke dalam layar HP pengguna, untuk menggunakan promo tersebut pengguna bisa memilih salah satu iklan yang didapat kemudian akan diarahkan ke halaman detail promo sehingga pengguna bisa melihat promo dengan lebih jelas lagi, karena didalamnya terdapat iklan promo yang ditawarkan beserta dengan $\mathrm{QR}$ code.

Pada halaman ini terdapat tombol "Check in" untuk memberikan info kepada khalayak bahwa saat ini pengguna sedang berada di lokasi merchant. Terdapat juga tombol "Show Map" untuk melihat rute menuju lokasi merchant melalui sebuah peta, dimana aplikasi akan mengirim koordinat lokasi tujuan ke server untuk selanjutnya server akan mengirimkan peta beserta rute terpendek sampai ke lokasi merchant berada dengan menggunakan perhitungan algoritma bee colony optimization. Terdapat juga tombol "Call Merchant" untuk menelpon merchant, aplikasi ini juga menyediakan tombol "Share Promo" untuk para pengguna yang ingin membagikan promo ke media sosial. Serta tombol "Subscribe" jika pengguna ingin berlangganan produk yang ditawarkan. Setelah melihat detail promo maka pengguna bisa sampai ke lokasi merchant yang akan di tuju.

\section{HASIL}

Pada rancangan sisi client dibuat tampilan antarmuka aplikasi yang berfungsi sebagai alat untuk berkomunikasi antara pengguna dengan sistem. Pada awal tampilan menu utama, sistem akan menmapilkan pilihan menu diantaranya menu My Location, menu Product List, menu Promo List, serta menu Help atau bantuan. Gambar 2 menunjukkan tampilan halaman menu utama dari aplikasi pada sisi client.

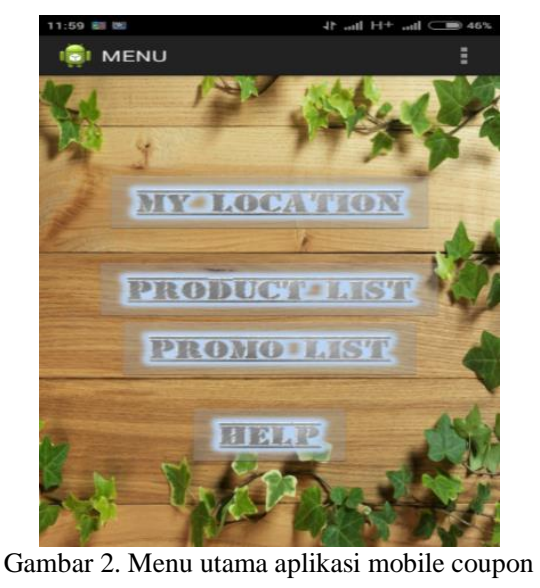

Apabila menu My Location di klik, maka program akan melakukan intent yang artinya akan memanggil class MyLocation untuk startActivity atau memulai aktifitasnya Adapun gambar 3 merupakan tampilan dari menu My Location.

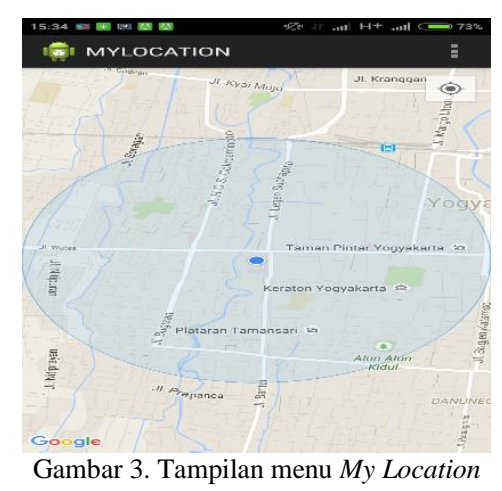

Selanjutnya apabila menu Product List di klik, maka program akan melakukan memanggil class ProductList untuk startActivity atau memulai aktifitasnya menampilkan sebanyak 21 kategori dari produk yang ditawarkan. Adapun gambar 4 merupakan tampilan dari menu ProductList. 


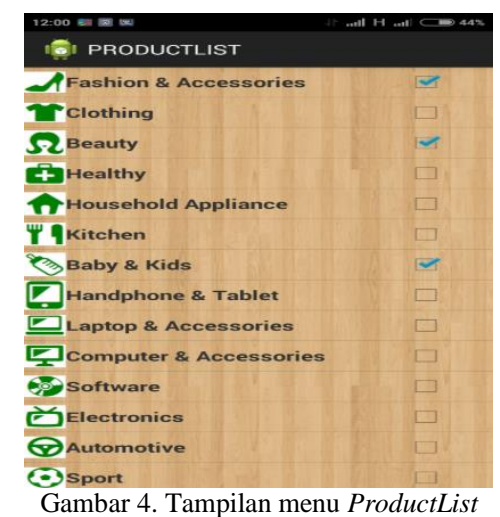

Selanjutnya apabila menu PromoList di klik, maka program akan memanggil class PromoList untuk startActivity atau memulai aktifitasnya menampilkan berbagai promo yang sedang berlangsung. Promo ini ditampilkan berdasarkan lokasinya yang terdekat dengan pengguna. Adapun gambar 5 merupakan tampilan dari menu PromoList.

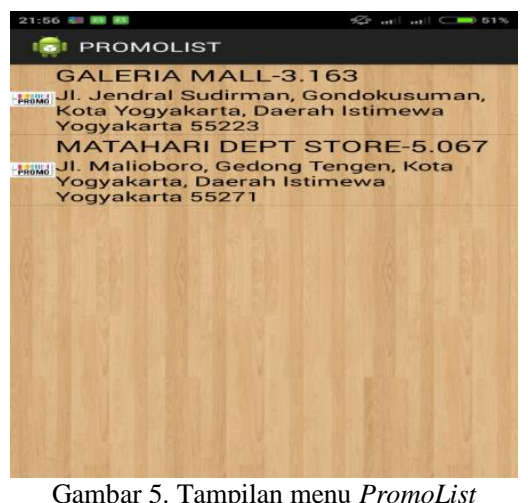

Dalam PromoList terdapat berbagai promo yang sedang berlangsung. Dimana bila user mengklik salah satu dari daftar promo yang ditampilkan makan user akan dibawa ke tampilan selanjutnya yakni bagian DetailPromo. Pada bagian ini selain melihat promo secara lebih detail, user juga dapat melakukan call merchant atau melakukan panggilan telepon ke merchant yang mengadakan promo, dapat juga melakukan share promo ke berbagai media sosial, melakukan check in ke lokasi yang dituju, menampilkan peta lokasi merchant sekaligus rute terpendek untuk menuju ke lokasi yang dituju. Serta melakukan subscribe promo jika user ingin berlangganan promo dari merchant yang dipilih. Adapun gambar 6 merupakan tampilan dari menu DetailPromo.

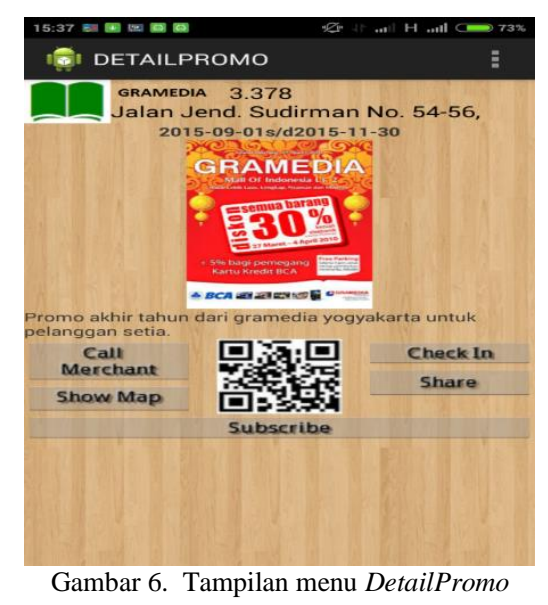

\section{PEMBAHASAN}

Pengujian berdasar tujuan dilakukan untuk melihat keberhasilan menemukan rute terpendek menuju lokasi merchant. Pengujian ini dilakukan dengan menggunakan parameter yang sama yaitu jumlah lebah (NBee) $=100$, $\alpha=1, \beta=2, \lambda=0.7, \mathrm{~K}=1$. Jumlah merchant tujuan yang diuji sebanyak 10 lokasi. Adapun hasil pengujian dengan 1 merchant tujuan dapat dilihat pada Tabel I.

Dari pengujian diketahui bahwa terdapat sebanyak $100 \%$ percobaan yang berhasil menemukan lokasi merchant tujuannya. Pengujian selanjutnya dengan membandingkan jarak dari hasil perhitungan dengan Google Maps. 
Pengujian ini dilakukan dengan posisi asal dari perempatan Tugu Jogja. Nilai parameter yang digunakan yakni NBee $=50, \alpha=1, \beta=2$, dan $\lambda=0.7$ dan $K=1$. Hasil perbandingan untuk 1 merchant tujuan seperti pada Tabel II.

TABEL I

HASIL PENGUJIAN MENCARI RUTE TERPENDEK MENUJU LOKASI MERCHANT

\begin{tabular}{cccc}
\hline No & Posisi asal & Merchant & Keterangan \\
\hline 1 & T3 & M00001 & Berhasil \\
2 & T16 & M00004 & Berhasil \\
3 & T19 & M00005 & Berhasil \\
4 & T30 & M00008 & Berhasil \\
5 & T78 & M00011 & Berhasil \\
6 & T3 & M00012 & Berhasil \\
7 & T16 & M00033 & Berhasil \\
8 & T19 & M00039 & Berhasil \\
9 & T30 & M00042 & Berhasil \\
10 & T78 & M00047 & Berhasil \\
\hline \hline
\end{tabular}

TABEL II

HASIL PERBANDINGAN SISTEM DENGAN GOOGLE MAPS

\begin{tabular}{clcccc}
\hline \hline \multirow{2}{*}{ Posisi asal } & \multirow{2}{*}{ Merchant } & \multicolumn{2}{c}{ Total Jarak (km) } & \multicolumn{2}{c}{ Keterangan } \\
& & Sistem & Google Maps & Sistem & Google Map \\
\hline T16 & M00001 & 3.9 & 3.9 & Berhasil & Berhasil \\
T16 & M00004 & 1.2 & 1 & Berhasil & Berhasil \\
T16 & M00005 & 3.5 & 3.5 & Berhasil & Berhasil \\
T16 & M00008 & 3.6 & 3.6 & Berhasil & Berhasil \\
T16 & M000012 & 5 & 5 & Berhasil & Berhasil \\
\hline \hline
\end{tabular}

Dari percobaan memperlihatkan bahwa sistem mampu menemukan tujuan dengan jarak yang mendekati penelusuran Google Maps. Namun sistem membutuhkan waktu lebih lama dibanding Google Maps, hal ini karena pengaruh dari banyaknya jumlah lebah yang dilepas.

Berdasarkan pengujian untuk mengetahui performa algoritma lebah dalam pencarian rute terpendek didapat hasil bahwa pencarian rute terpendek menggunakan konsep heuristik memperbesar peluang ditemukannya rute perjalanan yang lebih pendek bila dibandingkan dengan konsep konvensional. Penerapan algoritma BCO ini secara umum dapat digunakan untuk mencari rute terpendek. Faktor yang paling berpengaruh adalah jumlah lebah yang dilepas. Sistem ini menelusuri jalur yang mungkin sesuai dengan lebah yang dilepas. Semakin banyak lebah yang dilepas, maka semakin besar peluang menemukan rute yang terpendek.

\section{SIMPULAN}

Berdasarkan penelitian yang telah dilakukan serta hasil pengujian dari aplikasi LBS sebagai sarana promosi dengan teknik layanan mobile coupon, maka dapat diambil kesimpulan sebagai berikut:

1) Sudah dapat dibangun aplikasi yang dapat menampilkan iklan atau promosi dari para merchant di wilayah Daerah Istimewa Yogyakarta sesuai dengan produk yang telah dipilih oleh user.

2) Kupon promosi yang ditawarkan sudah dapat terintegrasi dengan QR Code.

3) Promo sudah berhasil dikirim melalui push notifikasi kepada user yang mencari promo.

4) Pencarian rute terpendek dengan bee colony mampu menemukan tujuan dengan jarak yang mendekati penelusuran Google Maps. Namun kurang efektif dari segi waktu pemrosesan, karena semakin banyak jumlah lebah yang dilepas maka semakin lama waktu pemrosesan.

\section{REFERENSI}

[1] Firman, M. dan Nur, A., 2011," Telkomsel Fokus Ke Layanan Data". Available at: http://teknologi.vivanews.com/news/read/254883-telkomsel-fokuske-pengguna-layanan-data. diakses tanggal 30 Oktober 2014.

[2] Kumar, S., Qadeer, M.A., and Gupta, A., " Location Based Service Using Android", Departement of Computer Engineering Zakir Hussain College of Engineering and Technology, India, 2009.

[3] Wibowo. H., Lestari. U., dan Triyono. J., "Sistem Informasi Potensi Industri Di Kabupaten Bantul Berbasis Geographic Information System Dan Location Based Service", Jurnal SCRIPT Vol. 1 No. 2 Januari 2014, ISSN:2338-6304.

[4] Imaniar, J., Arifin, dan Khalilullah, A.S., “Aplikasi Location Based Service Untuk Sistem Informasi Publikasi Acara pada Platform Android”, Jurusan Teknik Telekomunikasi, Politeknik Elektronika Negeri Surabaya, Surabaya, 2011, pp. 1-5.

[5] Kushwaha. A., Kushwaha. V.," Location Based Service using Android Mobile Operation System”, International Journal of Advances in Engineering \& Technology (IJAET), ISSN: 2231-1963, 2011, pp. 14-20.

[6] Machrus, A.M., Supriyanti, R., dan Ramadhan, Y., "Rancang Bangun Aplikasi Clinic Finder Berbasis Android Di Kabupaten Banyumas", Teknik Elektro, Universitas Jenderal Soedirman, Purbalingga, 2013.

[7] Pratama. G. T, Ciptaningtyas. H., dan Anggraini. E. L, "Pencari SPBU Terdekat Menggunakan Layanan Berbasis Lokasi Berdasarkan Sensor Pada Indikator Bensin Untuk Ponsel Android”, Jurnal TEKNIK POMITS Vol. 2, No. 1, ISSN: 2337-3539 (2301-9271 Print), 2013. 
Jurnal Informatika dan Komputer (JIKO) - Vol. 1, No. 2, September 2016

[8] Hanafi, "Sistem Aplikasi Mobile Advertising Berbasis Grafis dan Animasi”, Thesis, Jurusan Pascasarjana Teknik Elektro dan Teknologi Informasi, Fakultas Teknik, Universitas Gajah Mada, Yogyakarta, 2012.

[9] Ikhsandio, R., "Pengembangan Server Aplikasi Location Based Advertising Dengan Menggunakan Web Service", Komputer dan Sistem Informasi, Skripsi, Jurusan Ilmu Komputer dan Elektronika, Fakultas MIPA, Universitas Gajah Mada, Yogyakarta, 2013.

[10] Prasetyo, A.D., "Implementasi Location Based Advertising dengan Selected Push Berbasis Android", Jurusan Ilmu Komputer dan Elektronika, Fakultas MIPA, Universitas Gadjah Mada, Yogyakarta, Indonesia, 2013.

[11] Rahmady R.J., 2013, Aplikasi Location Based Advertising dengan Metode Push dan Pull pada sistem Operasi Android, Jurusan Komputer dan Sistem Informasi, Universitas Gajah Mada, Yogyakarta.

[12] Smart, W. M. , 1960, Text-Book on Spherical Astronomy, 6th ed. ,Cambridge, England: Cambridge University Press. Available at https://archive.org/details/SphericalAstronomy 